Charlotte Helen Haaland Hancock

University of Stavanger

Unni Vere Midthassel

University of Stavanger

Hildegunn Fandrem

University of Stavanger

DOI: http://doi.org/10.5617/adno.8381

\title{
Upper Secondary Teachers’ Experiences Promoting Belonging and Engagement in Culturally Diverse Classrooms
}

\begin{abstract}
The aim of this study was to investigate upper secondary teachers' experiences of promoting belonging and engagement in culturally diverse classrooms. The selected teachers in this study were employed in two upper secondary schools and had substantial experience in teaching in culturally diverse classes. They participated in focus group interviews to discuss their experiences. The interview topics were relationships in class, academic and social learning, discrimination and victimisation, academic resources and expectations, adaptation and support in learning activities. The interview data were transcribed, analysed and discussed using thematic analysis. The findings showed that the interviewed teachers considered 1) teacher-student relationships, 2) acceptance of diversity and student-student relationships, and 3) participation in learning activities to be important aspects of students' belonging and engagement. Moreover, the findings indicated challenges in creating stable relationships to promote cross-cultural friendships. Based on these findings, teachers need more strategies to develop cross-cultural friendships. Furthermore, teachers need to know how and when to intervene in situations of exclusion or segregation. For the prevention of exclusion and segregation, it is important to further develop knowledge of how to promote belonging and engagement among culturally diverse student groups.
\end{abstract}

Keywords: belonging, engagement, newly arrived immigrants, teaching, upper secondary school

\section{Læreres erfaringer med å fremme tilhørighet og engasjement i flerkulturelle klasser i videregående skole}

\section{Sammendrag}

Formålet med studien var å undersøke hvilke erfaringer lærere hadde med å fremme tilhørighet og engasjement i flerkulturelle klasser i videregående skole. Lærerne som deltok i denne studien, var fra to videregående skoler og hadde lang erfaring fra flerkulturelle klasser. De deltok i fokusgruppeintervju for å diskutere sine erfaringer. Tema som ble tatt opp i intervjuene var relasjoner i klassen, akademisk og sosial læring, 
diskriminering og mobbing, akademiske ressurser og forventninger, tilpasning og støtte i læringsaktiviteter. Intervjudata ble transkribert, analysert og diskutert ved bruk av tematisk analyse. Funnene viste at lærerne mente at 1) lærer-elev relasjoner, 2) aksept for mangfold og elev-elev relasjoner, og 3) deltakelse i læringsaktiviteter var viktige aspekt for elevenes opplevelse av tilhørighet og engasjement. Funnene indikerer videre at det er vanskelig å etablere kryss-kulturelle vennskap. For å løse dette trenger lærere strategier for å utvikle kryss-kulturelle vennskap mellom elever. Videre implikasjoner av funnene tilsier at lærere har behov for å vite hvordan og når de skal intervenere $\mathrm{i}$ situasjoner hvor det oppstår ekskludering eller segregering. For å forebygge ekskludering og segregering er det nødvendig med mer kunnskap om hvordan fremme tilhørighet og engasjement blant elever i flerkulturelle klasser.

Nøkkelord: tilhørighet, engasjement, nyankomne elever, undervisning, videregående skole

\section{Introduction}

In Norway, as in other Western countries, upper secondary classrooms are diverse and pluralistic. Migration due to oppression and war has contributed to many young immigrant students settling in Norway in the recent decades. $17 \%$ of all students (34,103 students of a total of 199,401 in 2018) have immigrant backgrounds in Norwegian upper secondary school (SSB, 2018). In this study, immigrant students refer to students with short residency (2-6 years). However, immigrant students' diversity is not related to the cultural dimension alone. Both immigrant and other students may be diverse in aspects such as gender, religion, interests, sexual orientation, personal experiences and learning abilities (Allan, 2007; Biesta, 2006; Fandrem et al., 2015; Skrefsrud \& Østberg, 2015). Thus, a culturally diverse classroom can be understood to include several dimensions of socio-cultural differences. Moreover, culturally diverse classrooms are not diverse solely in the sense that the students differ from each other; every student also brings in different sociocultural dimensions as part of their individual identities. Students' culture and identity are dynamic and cannot be reduced to one singular membership (Sen, 2006). Though immigrant students are in focus in the present study, other aspects of diversity are also taken into account.

International and national research has shown that many immigrant students struggle to reach their educational aims (Andon et al., 2014; Rogstad \& Reegård, 2016). Despite several decades of work with culturally diverse classrooms, disengagement and marginalisation among immigrant students seem to be a challenge in most Western countries (Gay, 2018). However, culturally diverse classrooms represent opportunities for student learning about different cultures, norms, and values alongside academic learning, which is important for overcoming discrimination, exclusion, prejudice, stereotypes and racism, and promoting interaction between students from different cultures. According to previous research, the promotion of such interaction presupposes an acceptance 
of diversity among the students in the class (KC \& Ohna, 2021; Solbue et al., 2017). Moreover, learning to work together in a pluralistic society has been emphasised as important (Gay, 2018). Previous findings have identified stronger feelings of belonging for all students who experience positive interaction in culturally diverse classrooms (Schachner et al., 2019). Solbue et al. (2017) note that acceptance for diversity is a component in the enhancement of interaction in class. According to their findings, teachers need to focus more on interaction during teaching than categorisation based on ethnicity, gender, linguistic or social backgrounds. However, studies exploring more in depth how teachers may focus on interaction are scarce.

This study aims to explore teachers' practices and reflections on teaching in culturally diverse classrooms as they seek to enhance belonging through improved interactions between students. The objective is to gain knowledge of how teachers can promote belonging and engagement in upper secondary school and, more specifically, how they reflect on possibilities and challenges within their teaching practices when it comes to improving interactions between students.

\section{The Norwegian educational context}

All youth in Norway have a statutory right to proceed into an upper secondary educational programme after grade 10 of compulsory school, regardless of their previous academic achievement. 98\% of all youth begin upper secondary school immediately after lower secondary school (NOU, 2018, p. 15). Students choose between two major paths, vocational or academic. Dropout rates are higher in vocational programmes (40\%) than in academic programmes (13\%) (SSB, 2019). Based on recent national statistics (SSB, 2019), 25.5\% of all students do not complete upper secondary school after five years, and first-generation immigrants are particularly overrepresented (Markussen et al., 2006), with as much as 45\% not completing upper secondary school after five years (SSB, 2019).

\section{Promoting a sense of belonging in schools}

The need for belonging is a psychological aspect for which meaningful and stable social relationships are of special importance (Baumeister \& Leary, 1995). In this paper, the focus is on school belonging, which refers to belonging related to the school context. School belonging may be defined in different ways and may be related to other concepts (Allen \& Bowles, 2012). These concepts often include the experience of connection to school, perceptions of relationships with peers and teachers, and feelings of being safe and supported. Although these aspects relate to psychological processes within an individual (Libbey, 2004), they also occur in a contextual setting: in school with teachers and peers working together on learning activities.

In describing belonging in school, The Wingspread Declaration from 2004 (Allen \& Bowles, 2012) pinpoints teachers' work in applying high standards of expectations and support to all students, implementing fair and consistent 
disciplinary policies, and developing trusting relationships (Allen \& Bowles, 2012). Therefore, promoting a sense of school belonging means supporting all students in feeling and doing well at school. Thus, the focus should be on the whole class community.

In addition, Makarova and Herzog (2013) emphasise that feelings of belonging are associated with positive attitudes towards learning and are especially related to academic self-efficacy. This view suggests that belonging in school is related to engagement in school through emotional engagement. Thus, the emotional aspect of engagement is a special focus in this paper (Christenson et al., 2012).

Several studies have focused on the relation between school belonging and engagement. Studies concerning dropout in upper secondary school often include explanations of what teachers do to prevent disengagement in general (Christenson et al., 2012). Moreover, previous research suggests that a sense of belonging can influence students' engagement through motivation, self-efficacy and effort (Goodenow, 1993). Encouraging motivation and making learning relevant are thus key elements for teachers. Setting academic expectations through highquality, responsive relationships between teachers and students is also essential (Kiefer et al., 2015). Students who experience belonging tend to achieve more and like school more (school values) than students who do not experience belonging (Gillen-O'Neel \& Fuligni, 2013). Notably, however, the association between school belonging and engagement may operate in both directions, possibly in a mutually reinforcing manner. That is, the more engaged students are, the stronger their sense of belonging to school, and the more strongly students feel they belong to school, the more actively they engage academically (Juvonen et al., 2012).

\section{Teacher support as an important aspect influencing belonging}

According to Allen and Kern (2019), among various factors, teacher support has the strongest influence on belonging. In line with these findings, Osterman (2000) highlights the role of the teacher in supporting students both academically and personally. Furthermore, Thapa et al. (2013) claim that perceived teacher support is one of the most important factors in the classroom environment. Students who report that their needs are met, feel a greater sense of belonging than those who do not report their needs being met (Gillen-O’Neel \& Fuligni, 2013).

Consequences of exclusion and victimisation have been well documented in previous research (Breivik et al., 2017). More specifically, research shows that both victims and bullies report experiencing disconnectedness and insecurity. In particular, verbal victimisation, such as teasing or mocking, is associated with a lack of feelings of belonging (O’Brennan \& Furlong, 2010). Peer victimisation affects belonging and commitment to school, and exclusion may lead to emotional distress and loneliness (Thapa et al., 2013). Students' experience of rejection or exclusion is also associated with negative consequences such as lower achievement and dropout. Therefore, teachers have a responsibility to detect and intervene in peer victimisation if it occurs (Thapa et al., 2013). Based on research on 
victimisation, teacher support is important for preventing, identifying and reacting to peer victimisation, prejudice and racism.

According to Kiefer et al. (2015), teachers have an important role in modelling respectful behaviour, stating classroom norms, and encouraging students to interact with each other in a respectful manner. Through their behaviour, teachers promote a sense of safety and security, which enables a focus on learning. Feeling safe in class is essential for both learning and well-being (Thapa et al., 2013).

Immigrant students in upper secondary school and the role of peer relations Achievement and dropout are complex processes and are related to many different factors for immigrant students (Rogstad \& Reegård, 2016). Immigrant students' achievements and attitudes towards school and the quality of their relationships with peers and teachers are related to disengagement. However, these aspects are associated not only with general school dropout but also with hidden dropout among immigrant students (Makarova \& Herzog, 2013). Hidden dropout refers to students attending class but still being disengaged from learning processes, according to Makarova and Herzog. Although immigrant students' sociodemographic characteristics largely explain the major causes of immigrant students' academic performance or achievement levels, "there remains an unexplained residual of immigrant underachievement in some countries" (Simon et al., 2007, p. 49).

Relationships between students can offer acceptance and support and promote students' feelings of inclusion in class. Tartakovsky (2007) reports that immigrant upper secondary students in Israel who perceived social support from friends had less acculturative stress and homesickness than those without such support, but that perceived parental social support did not influence the same aspects. Moreover, in a recent study, poor peer relations, in terms of both victimisation and loneliness in school (measured with items such as "I have no one to be together with at school") were associated with intentions to quit school (Fandrem et al., 2021), and the associations between loneliness and intensions to quit were significantly stronger for the first-generation immigrant group than for the native Norwegian group of students. Hamm and Faircloth (2005) state that friendships can make students feel more academically and socially engaged, but they also claim that friendships do not always provide a sense of belonging to the school as a whole. For example, within culturally diverse classrooms, small groups of friends tend to form "cliques" with similar students. Consequently, experiencing a lack of acceptance, relationships and friendships can lead to feelings of alienation (Hamm \& Faircloth, 2005). Thus, it is important that teachers encourage and facilitate group work and projects in which students work together across cultural backgrounds (Gay, 2018). By encouraging students to collaborate on learning activities, teachers can engage students in accepting and valuing each other. Students can then relate to other peers outside their bonds of friendships through mutual helping and sharing. 


\section{The current study}

The specific aim of this study is to explore 1) teachers' experiences promoting belonging among newly arrived immigrant students in upper secondary school, including their challenges in promoting belonging in culturally diverse classrooms. A sub-aim is to investigate 2) teachers' experiences of facilitating engagement in culturally diverse classrooms in upper secondary schools, including their actions to prevent disengagement.

We are especially interested in how teachers promote belonging through student-student interactions during learning. Very few studies have explored how teachers perform in these practices in upper secondary school. There is a need for more research on these aspects in educational research, especially because few qualitative studies have provided an in-depth understanding of the promotion of belonging and engagement in culturally diverse upper secondary classrooms. This study aims to fill this research gap.

\section{Materials and methods}

\section{Data collection and procedure}

Focus group interviews with teachers were used as the data collection method. The purpose of the interviews was to attain deeper insight into aspects of belonging and engagement. Focus group interviews depend on the reflections and discussions made by the group (Krueger \& Casey, 2015). Such interviews highlight nuances in participants' experiences, and interactions between participants generate data (Tjora, 2017). There were no expectations of reaching a consensus or conclusion during the interview. The teachers were also able to discuss conflicting viewpoints (Kvale \& Brinkmann, 2015).

The focus group interviews were semi-structured. Concepts from the theoretical framework of the study were used to develop topics and questions to create a structured interview guide. The aim was to explore topics that were closely linked to belonging and engagement, for instance, teachers' work related to relationships in class, safety, the organisation of learning activities, academic and social learning, discrimination and victimisation, academic resources and expectations, and support in learning activities. The questions were open-ended but structured around these central topics. The interviewer acted as a moderator who introduced guidelines for the interview, asked questions and facilitated the discussion. The interview guide included follow-up questions that encouraged teachers to give examples of what they actually do in class to ensure good group dynamics. The interviews were conducted at the schools and lasted for approximately 60-70 minutes. All interviews were audiotaped and transcribed afterwards. 


\section{Informants}

The 11 participating teachers were recruited from two different upper secondary schools taking part in a national project called Competence for diversity (Lødding et al., 2018). This project was a national initiative to gather information on competence and experiences related to diversity with particular reference to immigrant students. The governmental authorities for education initiated the project. Convenience sampling was used to select interview participants. The teachers were part of a diversity programme and were employed at schools with student diversity in terms of culture, ethnicity and nationality. The teachers' classes were part of the Health and adolescence vocational programme, which consists of two years of schooling and two years of apprenticeship in a workplace such as a school, hospital or pre-school. The teachers had extensive experience working with immigrant students. The teachers were all white, female and aged 32-50 years, and they had an average of 9 years of experience teaching in secondary school. One urban municipality in Norway participated in this study. The two schools represented are public schools and are defined as large, as they each have several educational programmes and a student population of approximately $700-800$ students.

\section{Contextual features}

In the first school, 90 students participated in the Health and adolescence programme, including two immigrants who had lived in the country for less than 6 years. In the second school, 120 pupils participated in the programme, and approximately $40 \%$ of the students had immigrant backgrounds. In this study, we focused on newly arrived immigrants who came from Afghanistan, Eritrea, Ethiopia, Somalia, and Iran, and had lived in Norway for 3-5 years. Some of these students were unaccompanied minor asylum seekers. They had permanent residency. We did not acquire any information on reasons for migrating or health status after migrating. Due to ethical restrictions, the schools and teachers were not allowed to provide detailed personal information or information about students' ethnicity, language, religion, or health status that could lead to students being identified by others.

The schools formalised peer relationships through a programme called "VIPmakkerskap". A key element of this programme is that teachers organise partnerships between students. In these partnerships, pairs of students collaborate on lessons and projects for specific subjects. Teachers change the pairs periodically. By the end of the school year, each student has collaborated with different students in class. The aim of the programme is to establish safe peer relations and promote well-being.

\section{Qualitative analysis}

The interview data were analysed through deductive coding based on predetermined concepts from theory and research. The main aim was to analyse the data 
following the thematic analysis approach, according to which interesting units of data were organised into meaningful groups (Braun \& Clarke, 2006, p. 88). First, transcripts from the focus group interviews were summarised. The objective was to perform meaning condensation. This step can be described as first-cycle coding (Miles et al., 2014). It included repetitive reading of the transcripts to find meaning in the teachers' statements. The statements were analysed based on exemplifying codes, categories and themes. Themes were developed from the codes that were inspired by the concepts in the interview guide. A second cycle of coding was important to identify the meaning of and relations between codes, categories and themes. In this second cycle, new codes were identified, and themes emerged. Consequently, the findings became more interesting and began to clarify the context of the participants. This step involved actively interpreting the data and creating meaning (Silverman, 2000). We used a semantic approach to analyse teachers' explicit statements (Braun \& Clarke, 2006, p. 84). In the thematic analysis, some coherent themes emerged. The aim was to develop themes with "thick descriptions" of multiple views of school belonging and engagement (Beitin, 2012). The importance of contextual features emerged as a vital part of understanding the themes, which confirmed the importance of thinking about context rather than content (Beitin, 2012).

We used NVivo 11 (QSR International) to organise and categorise the data. Codes (nodes) were created to categorise the data thematically. Key concepts from the interview guide and theory formed the foundation for analysis and interpretation. The main codes developed in NVivo were relationships, academic and social participation, exclusion and victimisation, the learning environment in class, resources, challenges, adaptation and academic support. Through the analysis, we identified three main themes: teacher-student relationships, acceptance of diversity and student-student relationships, and engagement and participation in learning activities. Two researchers conducted the categorisation of themes. The researchers were white Norwegian. They have experience with cultural diversity, having worked on topics such as diversity, minorities, discrimination, racism, and exclusion/inclusion both in schools and research. However, their background in an individualistic culture may make them less open to values in collectivistic cultures and may thus add to the complexity of interpreting cultural diversity. Qualitative research is never neutral (Kvale \& Brinkmann, 2015). The researchers bring their backgrounds, theoretical choices, and own experiences and interests to their interpretation of the informants' expressions.

\section{Ethics}

The teachers signed a letter of consent, approved by the Norwegian Centre for Research Data (NSD). As an introduction to the interview, the teachers were reminded that students' names, age, ethnicity, gender, medical diagnoses and any other personal issues about students and colleagues would be kept strictly confidential. The NSD restricted teachers from giving confidential information during 
interviews. The anonymity of the teachers in the transcriptions and publications was ensured throughout the research process. Ethical committees and national policy strictly regulate confidentiality and anonymity to protect all participants (Kvale \& Brinkmann, 2015).

\section{Findings}

The research aims concerned how teachers promote belonging, especially for immigrant students with short residency. We also focused on how teachers facilitate engagement through their understanding of belonging. We found that the teachers were actively working to promote aspects of belonging and engagement to enhance learning in culturally diverse classrooms. The findings are presented according to the three themes identified in the analysis.

\section{Teacher-student relationships}

Concerning our first aim, our data show how the teachers described their commitment to promoting safe and stable relationships with students. More specifically, the teachers discussed how they actively participated in different social activities with students at the start of the school year. They expressed how important it is to establish relationships with new students by initiating activities such as games and day trips. Teacher-student relationships constituted an important topic for the teachers. One of the teachers explained how a democratic leadership style encourages students to be autonomous:

We want to treat students like adults. We want to guide them more than tell them what to do. Several of our students come from cultures where they are brought up with great respect for teachers. They say to us, "Teacher, teacher, thank you very much teacher." They talk to us in a very polite way. We do not see this in Norwegian students. (Hanna)

All the teachers agreed that a learning environment characterised by independence and responsibility is different from a more structured learning environment. They suggested that students should be informed about the freedom and structure of a class, which may be different from their previous schooling experiences. Furthermore, the teachers talked about how their methods of teaching emphasised guidance and support. In one of the schools, the time schedule allowed two teachers to always be present in the same class. The presence of two teachers provided more time for the teachers to guide and support each student. The teachers explained that more time with each student helped them build stable teacher-student relationships. The teachers noted that they participated in numerous kinds of conversations with their students. As an example, the same school had eliminated the use of the "black book" with marks/grades on behaviour such as tardiness to class or interruptive behaviour. The teachers explained that they consequently could communicate more and create positive meetings with their 
students. The teachers seemed to be in favour of this change: "This has forced teachers who put black marks on students to instead enter into dialogue with them." (Anne)

Concerning challenges, the teachers explained situations related to vocational training, for which cultural differences appeared to be a relevant topic. The teachers viewed cultural diversity as an asset for the class. Nevertheless, one teacher mentioned a different aspect of working with immigrant students. Her opinions led to a new direction in the group discussion, with several teachers agreeing about dilemmas they had experienced in working with immigrant students. In practical work situations, immigrant students sometimes found it difficult to adjust to a professional role when interacting with children or elderly individuals in kindergartens or nursing homes, respectively. For example, some students spoke to children in an authoritative and strict way. Emily reflected upon this from her experiences with students in kindergarten:

Some of the immigrant students assume that they should take on a parenting role. They scold the children as if they were their own. "Oh, stop, stop, stop. You cannot do that. You are supposed to be professional. You should focus on children's learning and coping, not on upbringing." [Emily, referring to herself] You need to make them understand the difference. (Emily)

Several of the teachers agreed and gave examples of similar situations in the context of kindergartens and nursing homes. They explained how they guided immigrant students concerning norms of Norwegian upbringing. Similar situations occurred in nursing homes for elderly people. Teachers described situations in which students could not wash their arms and hands because of cultural norms. One teacher emphasised that it is important to clarify expectations, for example, expectations regarding hygiene, in certain professions. The teachers explained that they were flexible in terms of the ways a profession could be practised; however, in some cases, it was necessary to guide students on requirements within their future professions.

\section{Acceptance of diversity and student-student relationships}

Regarding our first aim of understanding how teachers promoted belonging, another theme emerged. All of the teachers expressed that there was an acceptance of diversity. The teachers elaborated that this acceptance created a learning environment with tolerance for differences in opinions and beliefs. Furthermore, the teachers had observed students being curious about and interested in other students' upbringing or traditions. Some of the teachers mentioned that students were used to the presence of students of different cultures in class. Moreover, the teachers reflected that this familiarity with cultural diversity could help reduce prejudice and promote the acceptance of differences in appearance, opinions and religion. Teachers in one of the interviews expressed that teaching in culturally diverse classrooms was a resource. The teachers from this school explained that 
they organised several activities, such as those featuring the dances, food, costumes, music and traditions of different countries and cultures.

The teachers discussed the importance of promoting opportunities for students to establish relationships with peers in class. Exclusion and segregation appeared to be important themes related to challenges in promoting belonging. The teachers described situations during breaks or lunch when students mixed only with other students with a common background, language or religion. Several times, the teachers expressed that immigrant students preferred to be with peers with a similar background. The teachers believed such interaction provided students with a feeling of safety and security.

I remember last semester. We were in this classroom and had lined up two tables, one here and one there. The immigrant students went to one table, and the ethnic Norwegian students went to the other table. We had not introduced the partnership programme at that time. It was interesting. I remember my colleague and I asked them, "Why have you sat down in this manner? It is very clear that you have grouped yourselves." (Kristin)

The teachers reported no current cases of bullying among immigrant students. Nevertheless, they did note situations when immigrant students might have felt excluded from the rest of the class, and they were uncertain if immigrant students participated in after-school activities. "Cliques" clearly occurred within the teachers' classes. One teacher recounted her experience when Norwegian students and immigrant students of various ethnicities divided into two main groups during breaks. Teachers also discussed conflicts between students from different countries, in which some students were very focused on other students' native countries.

Moreover, teachers seemed to experience difficulties when trying to promote belonging and facilitate engagement for immigrant students, who were often reserved. They thought it was difficult to include immigrant students in group tasks and learning activities. The teachers were especially concerned about these students. They explained that they tried to engage them in both activities with peers and learning activities by forming smaller groups to make them feel safer and to make it easier for them to express themselves more freely. Two of the teachers mentioned that they thought quiet students posed a challenge. They suggested that the reason might be that immigrant students may be troubled with emotional difficulties because they might have a strict upbringing at home with many duties and responsibilities. In addition, some of these students struggle with academic and social pressure and are often forgotten or overlooked by their peers or teachers.

Some teachers reported bad language to be a challenge, and they seemed to find that intervening in these situations was difficult. They noted that the language that students used could be perceived as funny, as a type of jargon, but they were unsure which students found such language funny and which students found it hurtful. 
Daily life at school should prepare students for what they meet. They may get used to talking nicely to each other. It is not for sure they think about this.

Oh, it is only words. They are friends. (Trudy)

I sometimes think that the words they use can seem discriminating. It is supposed to be funny, like slang. However, who thinks it is funny, and who finds it discriminating? Some of it can be discriminating. I do not recall all the words they use. It is often about how you look or what you believe in. The words were among friends. I sometimes think it is weird to talk like that to each other. Who considers it to be ok, and who experiences it as not ok? (Kristin)

This quotation is representative of what the teachers told us about students' potential experiences of subtle situations of discrimination, bullying or exclusion. The teachers also reported that some of the students seemed to be very conscious about where other students came from or which religion they belonged to, which could hinder inclusion.

I think exclusion happens. When several Norwegian students are talking in Norwegian... They become a very big group, and then three or four are not included. Often, these [students who are not included] are wearing hijabs and living a strict life with strict rules. There can be different reasons why, but maybe they [Norwegian students] do not dare to include them. It seems foreign to them. However, I noticed from the first day at school that they are in some ways grouped by religion. (Kristin)

However, the teachers also seemed to be aware of how the VIP-makkerskap programme worked as a buffer against exclusion. Overall, the teachers were positive about using the programme on a regular basis. It prevented the students from choosing their own groups; thus, no students were excluded from group tasks. Trudy explained that her students often asked to continue the programme throughout the year: "I experienced it as a good programme. It gives the students opportunities to collaborate with everyone.” (Trudy)

\section{Facilitating participation in learning activities}

The teachers reported that immigrant students were disciplined, positive, and motivated, which made them positive role models for other students. The teachers indicated that immigrant students were a valued asset to the learning environment. On the other hand, several of the teachers related obstacles to immigrant students' participation. They noted that students sometimes seemed to have difficulties understanding messages from teachers, for example, messages about when and where to hand in assignments. Many immigrant students had shortcomings in learning Norwegian. These students seemed to be reluctant to communicate or ask about misunderstandings, which could again lead to disengagement. Several of the teachers expressed uncertainty regarding immigrant students' degree of understanding. One teacher elaborated on this topic with an example of a time when some students were leaving class to visit the library: 
I think we adults talk a little too fast, and the Norwegian students talk a little too fast when they plan to do something. "Then, you do... we go down to work at the library." Then, the other students have not grasped what actually happened. Then, suddenly people stand up and go downstairs. ... We need to be conscious of those matters. Check if they [immigrant students] have understood and ask them to repeat. (Hanna)

Most of the teachers acknowledged that immigrant students need extra attention and time to learn new concepts and words. To prevent disengagement, they actively used a word bank with glossary terms with descriptions of the Norwegian word, the translated word and a visual picture, which could be helpful. Teachers encouraged students to write down difficult words during each learning session. Then, students could build a collection of words, making it easy to repeat content and meaning later on. Repetition was a key factor. In a recent survey at one school, reading comprehension was identified as a challenge for immigrant students, as described by a senior teacher:

It is frustrating to experience that the student understands but is unable to express the content. You have organised an oral presentation about a specific topic. You know that the students are prepared and have worked hard, but then they are unable to express their knowledge and understanding. In other cases, they have partly understood the topic but have insufficient knowledge of the remainder. They work hard to attain good grades, but in the end, language is a great obstacle. (Sarah)

The teachers offered thoughts about how they supported and adapted to immigrant students' educational needs. They noted that when immigrant students struggle with severe language problems or academic pressure, a solution may be to divide the academic year over a longer period. They presented examples when this solution had been an investment for learning even more Norwegian concepts and words. Consequently, they had observed students better succeed during the second year than the first year in upper secondary school. The teachers described good experiences with students who had divided the academic year in this way. In contrast, other students wanted to fit in, be regular students and follow a consistent educational path. The teachers noticed that increasing awareness through teacher experience helped them identify difficult concepts, such as attitudes, needs and care. The teachers emphasised that extensive time is required to explain difficult concepts and words.

Moreover, the teachers expressed that topics within the subject Communication and interaction helped them encourage participation. Practical work situations in kindergartens and nursing homes created bonds and closeness among students. Teachers and students acquired common experiences during practical vocational training, and the teachers encouraged and supported students:

You can give feedback to the students in practical situations: "You were caring in your role as a kindergarten teacher when you comforted and supported the child." You see them so closely in the situations, so you can give the students feedback immediately. (Kristin) 
The competence aims related to Communication and interaction included developing communicative and social skills. Several teachers explained that practical projects and situations helped students develop relationships and social skills and gain learning experiences.

When you attend vocational education subjects within health and adolescence, you need to learn how to interact with people. Throughout the school year, you adapt to situations that are challenging or difficult. The requirement to work with different people or people you dislike is essential in their subsequent profession. (Anne)

The teachers emphasised both academic and social learning. Especially through vocational training situations, teachers tried to make learning relevant by preparing their students for work life. For the immigrant students, this was a complex process that involved attaining adequate language skills, theoretical knowledge related to specific subjects and professional development within a specific profession. The findings suggest the importance of relationships in class for providing students with learning and teachers' adaptation of learning to different situations through guidance and collaboration.

\section{Discussion}

The main objective of the study was to explore upper secondary teachers' experiences promoting belonging and engagement in culturally diverse classrooms. The findings show that the teachers emphasised that belonging and engagement concerned relationships and opportunities to participate in learning activities.

\section{Promoting belonging through supportive relationships}

\section{Student-teacher relationships}

The first aim of this study was to investigate teachers' expressions of how they promote school belonging. The findings indicate that teachers used numerous approaches to identify students' backgrounds and educational needs. They tried to find a space and place for interactions and informal conversations to show their interests in students during regular classroom practice. To some extent, this also included follow-up and guidance when students had their vocational practical training to be health care workers or pre-school assistants. To the teachers, this guidance during practical training was especially important for immigrant students. Different norms and expectations could create uncertainty and lead to failure for these students.

In line with previous research, the teachers highlighted the meaning of teacherstudent relationships. Having a positive relationship with at least one teacher is an important part of experiencing belonging (Allen \& Kern, 2019). Promoting a 
sense of belonging requires a secure classroom with stable relationships over time. Solbue et al. (2017) emphasise valuing students' thoughts, opinions, and needs. Furthermore, acceptance, empathy and recognition are important in culturally diverse classrooms (Solbue et al., 2017). Regular guidance in learning activities and vocational training situations provided teachers with insights about students' needs and strengths. The teachers in this study used these insights to create opportunities to support students, i.e., correcting misunderstandings and providing extra time or tools to improve language. Promoting positive attitudes towards learning could strengthen students' self-efficacy (Makarova \& Herzog, 2013). Our findings indicate that promoting positive attitudes and supporting immigrant students requires an understanding of how to provide extra support when needed.

\section{Student-student relationships and the teacher's role}

Concerning peer relationships, the VIP-makkerskap programme included structured peer activities in partnerships. This ensured daily interactions and collaboration with peers. The programme provided safety and predictability. However, we do not know the frequency and quality of these interactions and their associations with acceptance, respect and recognition. It is therefore difficult to conclude how the programme stimulates cross-cultural friendships beyond collaboration in learning activities. Teachers reported that during breaks and other informal activities, peers seemed to interact with students of similar cultural and religious backgrounds.

To experience belonging, students need to feel safe in class (Osterman, 2000). Furthermore, research shows that friendships and student connections promote belonging but that the degree of belonging depends on the content and quality of the relationships (Allen \& Kern, 2019). The teachers' reflections about segregation and exclusion indicate dilemmas regarding how and when to intervene in student relationships. In student relationships, the teachers were unsure about when to ask and intervene in subtle situations that could involve bullying and exclusion. Some teachers provided examples of the partial segregation of classroom interactions despite efforts to promote cross-cultural relationships, i.e., through classroom activities or VIP-makkerskap. We know from previous research that segregation and exclusion may occur when students form cliques or groups based on cultural background and/or religion (Hamm \& Faircloth, 2005). Some previous research, however, also shows that relationships with students of similar backgrounds provide support through language, positive emotions, attachment and friendships (St-Amand et al., 2017); thus, it might be important for teachers to monitor or investigate what peer relationships consist of. One teacher stated the importance of questioning: "We need to dare to ask. Too often, we don't dare to ask." When teachers observe students experiencing bullying, exclusion or segregation, they need to intervene. 
However, teachers may work preventively to promote prosocial norms to ensure safety and positive peer support by establishing classroom norms and rules (Kiefer et al., 2015) or by using specific programmes. The VIP-makkerskap programme could buffer against unsafety and loneliness, and several teachers encouraged students to do something nice for their fellow students during breaks. A lack of friendships or poor peer relationships could lead to students experiencing loneliness, which in turn is associated with intentions to quit school (Fandrem et al., 2021).

As head of the class, the teacher is in a unique position to develop relationships with students and to stimulate relationships between them. Respectful and supportive relationships between students can prevent bullying and exclusion. Stating norms and disciplinary policies is part of creating trusting relationships (Allen \& Bowles, 2012). Kiefer et al. (2015) findings show the importance of modelling respectful behaviour and stating classroom norms. This calls for teachers to focus on positive interactions in class and hence create a caring and supportive learning environment.

The teachers formed trusting and supportive relationships by being fair, supportive, and identifying and resolving challenges. The collective "we" (Eriksen \& Lyng, 2015) was to a great extent exemplified by students' interactions and participation and their mutual responsibility to support each other. These interactions were based on collaboration on learning tasks to develop a sense of classroom community; thus, the concept of community shaping didactics is also relevant here (Hansen, 2014). By focusing on how to work together on a task, i.e., using extensive collaboration, students learned to work with everyone, not just their friends. Teachers were responsible for choosing pairs and groups, which ensured routines and predictability in the collaborations. Social activities, discussions and group work strengthened the whole classroom community. In these activities, students learned and supported each other by working as a team. Still, the development of classroom practices to include a shared collective "we" requires further investigation. Such research could bridge the gap within teacher practices to help teachers develop the class as a classroom community by increasing intercultural capacity.

\section{Interaction to promote learning and prevent disengagement}

The second aim of the study was to explore how teachers promote engagement. Previous research from upper secondary schools indicates that there are few opportunities to interact in classrooms (Osterman, 2000). Previous studies also show that collaborative learning extends interactions between students (Gay, 2018; Osterman, 2000). Our study indicates that teachers ensure several interaction opportunities through discussions, group work, planned activities and learning tasks. In vocational education, such as that in the two studied schools, the teachers focus on interaction and collaboration to encourage learning; thus, they focus on emotional engagement. Moreover, extensive collaboration gives 
teachers insights into their students so they can guide them both academically and socially. They reflect on how they can facilitate and support learning, which can be understood as methods to prevent dropout in upper secondary schools (GillenO’Neel \& Fuligni, 2013).

The study findings further indicate that through dialogue and collaboration, teachers identify challenges students experience with language or subjects. Some of the teachers in this study focused on adapting learning, providing tools such as glossary books, visual boards, and extra time for language lessons. In meeting immigrant students, teachers promoted collaboration and participation through involvement in adapted learning activities. In addition, they believed in their students and that their students could succeed, which is important according to Hersi and Watkinson (2012). Succeeding, or feeling engaged, may also lead to school belonging (Juvonen et al., 2012).

Teachers' efforts to support and understand students help them facilitate educational opportunities. In line with previous research, supporting students closely may prevent hidden dropout among students (Makarova \& Herzog, 2013). On the other hand, there are still possibilities to prevent disengagement by drawing on more students' previous experiences (Gay, 2018). This study shows that cultural aspects such as language, traditions and national celebrations were presented by immigrant students but not represented in the learning activities or curriculum. The teachers seldom mentioned this aspect; when they did mention it, it was only in reference to activities representing cultural traditions and festive celebrations, foods, costumes and dances. We find few examples of teachers connecting students' prior knowledge and experiences to ongoing learning activities (Gay, 2018), despite their awareness of the necessity of attention and time, especially regarding learning new words. Immigrant students could benefit from greater acknowledgement of their identity, norms, values, and prior knowledge. In teaching practices, there is a need to adapt education for more culturally diverse classrooms and relevant curricula (Gay, 2018). Becoming more attentive to the value of students' prior experiences and backgrounds could help develop intercultural capacity in class (Solbue et al., 2017).

\section{Implications}

Teachers' experiences and reflections are important for exploring challenges and possibilities for improving practice. The current findings indicate that teachers strive to promote belonging and engagement among immigrant students. To be culturally responsive, teachers themselves need to be part of a supportive environment. An implication for upper secondary school is that teachers should have access to supportive leadership and resources, which requires that each school has a set of common aims and values. The importance of support also indicates that schools need to provide teachers with resources and tools to create a supportive environment, which may have a significant impact on teachers' ability to support immigrant students. 
The current findings have identified features of belonging and engagement in culturally diverse classrooms. The perspectives presented by the teachers provide important insights into working with culturally diverse classrooms in upper secondary school. Our study shows that there might be challenges in creating stable relationships to promote student interactions and friendships. To solve these challenges, teachers need more knowledge on the development of crosscultural friendships and strategies to promote relationships between students. Collaboration is essential for promoting positive relationships, participation and learning among students. Nevertheless, our findings indicate that teachers need to be sure about how and when to intervene in situations of exclusion or segregation. There is a need within the field to further develop awareness and knowledge of how to promote belonging and engagement among newly arrived immigrants. These findings are a first step in providing insights into providing immigrant students access to learning in upper secondary school. Further research on implementation may contribute to new understandings of the mentioned implications.

\section{Limitations and future research}

This study investigated teachers' experiences in culturally diverse classrooms in upper secondary school. Limitations of the study concern the small sample size, as only two schools and eleven teachers participated. The teachers' reflections described a specific context and might or might not reflect their practices with students in other contexts. The limitation of the findings to a specific school context also means that there are limitations regarding the generalisability of the findings. In addition, classroom practices are difficult to comprehend merely from studying teachers' experiences. Future research may use observations or longitudinal questionnaires over time to more precisely identify resources and challenges in culturally diverse classrooms. Through observation, it is possible to investigate actual teacher and student interactions.

Future research should also include students' experiences with belonging and engagement. A relevant topic for further studies is the importance of student relationships and perceived support from peers. There is a need for more research, especially on how to establish cross-cultural relationships between students. Future research could also include indicators of the quality of peer relationships. Interventions or tools to promote belonging and engagement in culturally diverse classrooms are also relevant for investigation. 


\section{About the authors}

Charlotte Helen Haaland Hancock is a PhD fellow researcher at the University of Stavanger. Her main research interests are cultural diversity, upper secondary education, teacher education and professional learning.

Institutional affiliation: Norwegian Centre for Learning Environment and Behavioural Research, University of Stavanger, Rektor N. Pedersens vei 39, 4021 Stavanger, Norway.

E-mail: charlotte.hancock@uis.no

Unni Vere Midthassel is a professor in Educational Psychology and senior researcher at the University of Stavanger. Her main research fields are teacher education and development, implementation and school improvement research. Institutional affiliation: Norwegian Centre for Learning Environment and Behavioural Research, University of Stavanger, Rektor N. Pedersens vei 39, 4021 Stavanger, Norway.

E-mail: unni.vere.midthassel@uis.no

Hildegunn Fandrem is a professor in Education at the University of Stavanger. She has contributed to several research projects on acculturation, inclusion and diversity, victimisation and mental health among immigrant students.

Institutional affiliation: Norwegian Centre for Learning Environment and Behavioural Research, University of Stavanger, Rektor N. Pedersens vei 39, 4021 Stavanger, Norway.

E-mail: hildegunn.fandrem@uis.no

\section{References}

Allan, J. (2007). Rethinking inclusive education: The philosophers of difference in practice. Springer Science \& Business Media.

Allen, K. A., \& Bowles, T. (2012). Belonging as a guiding principle in the education of adolescents. Australian Journal of Educational \& Developmental Psychology, 12, 108119.

Allen, K. A., \& Kern, P. (2019). Boosting school belonging: Practical strategies to help adolescents feel like they belong at school. Routledge.

Andon, A., Thompson, C. G., \& Becker, B. J. (2014). A quantitative synthesis of the immigrant achievement gap across OECD countries. Large-Scale Assessments in Education, 2(1), Art. 7. https://doi.org/10.1186/s40536-014-0007-2

Baumeister, R. F., \& Leary, M. R. (1995). The need to belong: Desire for interpersonal attachments as a fundamental human motivation. Psychological Bulletin, 117(3), 497529. https://doi.org/10.1037/0033-2909.117.3.497

Beitin, B. K. (2012). Interview and sampling: How many and whom. In J. F. Gubrium, J. A. Holstein, A. B. Marvasti, \& K. D. McKinney (Eds.), The Sage handbook of interview research: The complexity of the craft (pp. 243-253). Sage. 
Biesta, G. (2006). Beyond learning: Democratic education for a human future. Routledge.

Braun, V., \& Clarke, V. (2006). Using thematic analysis in psychology. Qualitative Research in Psychology, 3(2), 77-101. https://doi.org/10.1191/1478088706qp063oa

Breivik, K., Bru, E., Hancock, C., Idsøe, E. C., Idsøe, T., \& Solberg, M. E. (2017). Å bli utsatt for mobbing. En kunnskapsoppsummering om konsekvenser og tiltak [Being exposed to bullying. A review about consequences and interventions] (pp. 33-68). Læringsmiljøsenteret.

Christenson, S. L., Reschly, A. L., \& Wylie, C. (2012). Handbook of research on student engagement. Springer.

Eriksen, I. M., \& Lyng, S. T. (2015). Skolers arbeid med elevenes psykososiale miljø-Gode strategier, harde nøtter og blinde flekker [Schools' work with students' psychosocial environment - Good strategies, tough nuts and blind spots]. NOVA rapport 14/2015. Norsk institutt for forsking om oppvekst, velferd og aldring. https://s3-eu-west1.amazonaws.com/cdn.sepu.no/supportfiles/Skolers-arbeid-med-elevenes-psykososialemiljo-NOVA-R14-15.pdf

Fandrem, H., Haus, S., \& Johannessen, Ø. (2015). Dette er Sevgi, er hun tyrkisk eller...? [This is Sevgi, is she Turkish or...?] In E. Kipperberg (Ed.), Når verden banker på - Nye utfordringer for profesjonsutøvelse [When the World knocks on - New challenges for professional practice] (pp. 135-156). Fagbokforlaget.

Fandrem, H., Tvedt, M. S., Virtanen, T., \& Bru, E. (2021). Intentions to quit upper secondary education among first generation immigrants and native Norwegians: The role of loneliness and peer victimization. Social Psychology of Education, 24, 489-509. https://doi.org/10.1007/s11218-021-09614-1

Gay, G. (2018). Culturally responsive teaching: Theory, research, and practice. Teachers College Press.

Gillen-O’Neel, C., \& Fuligni, A. (2013). A longitudinal study of school belonging and academic motivation across high school. Child Development, 84(2), 678-692. https://doi.org/10.1111/j.1467-8624.2012.01862.x

Goodenow, C. (1993). The psychological sense of school membership among adolescents: Scale development and educational correlates. Psychology in the Schools, 30(1), 79-90. https://doi.org/10.1002/1520-6807(199301)30:1<79::AID-PITS2310300113>3.0.CO;2-X

Hamm, J. V., \& Faircloth, B. S. (2005). The role of friendship in adolescents' sense of school belonging. New Directions for Child and Adolescent Development, (107), 61-78. https://doi.org/10.1002/cd.121

Hansen, H. R. (2014). Fællesskapende didaktikker [Community building didactics]. In H. R. Hansen \& D. M. Søndergaard (Eds.), Nye perspektiver på mobning [New perspectives on bullying] (pp. 63-72). Skolepsykologi. Den blå serie Nr. 31, Pædagogisk Psykologisk Tidsskrift.

Hersi, A. A., \& Watkinson, J. S. (2012). Supporting immigrant students in a newcomer high school: A case study. Bilingual Research Journal, 35(1), 98-111. https://doi.org/10.1080/15235882.2012.668869

Juvonen, J., Espinoza, G., \& Knifsend, C. (2012). The role of peer relationships in student academic and extracurricular engagement. In S. L. Christenson, A. L. Reschly, \& C. Wylie (Eds.), Handbook of research on student engagement (pp. 387-401). Springer US.

KC, B. K., \& Ohna, S. E. (2021). Preservice teachers' reflections on diversity and on teaching diverse pupils in Norwegian compulsory school. Acta Didactica Norden, 15(1), Art. 8. https://doi.org/10.5617/adno.7821

Kiefer, S. M., Alley, K. M., \& Ellerbrock, C. R. (2015). Teacher and peer support for young adolescents' motivation, engagement, and school belonging. RMLE Online, 38(8), 1-18. https://doi.org/10.1080/19404476.2015.11641184 
Krueger, R. A., \& Casey, M. A. (2015). Focus groups: A practical guide for applied research. Sage.

Kvale, S., \& Brinkmann, S. (2015). Interviews: Learning the craft of qualitative research interviewing. Sage Publications.

Libbey, H. P. (2004). Measuring student relationships to school: Attachment, bonding, connectedness, and engagement. Journal of School Health, 74(7), 274-283. https://doi.org/10.1111/j.1746-1561.2004.tb08284.X

Lødding, B., Rønsen, E., \& Wollscheid, S. (2018). Utvikling av flerkulturell kompetanse i lererutdanningen, grunnopplceringen og barnehagene. Sluttrapport fra evalueringen av Kompetanse for mangfold. [Development of multicultural competence in teacher education, primary education, and kindergarten. Final report from the evaluation of Competence for diversity]. NIFU, sluttrapport 2018:1. Nordisk institutt for studier av innovasjon, forskning og utdanning. https://www.udir.no/contentassets/0da7bd0dc463429e9132e56dbacfdbee/kompetanse-formangfold.pdf

Makarova, E., \& Herzog, W. (2013). Hidden school dropout among immigrant students: A cross-sectional study. Intercultural Education, 24(6), 559-572. https://doi.org/10.1080/14675986.2013.867603

Markussen, E., Lødding, B., Sandberg, N., \& Vibe, N. (2006). Forskjell på folk - hva gjør skolen? Valg, bortvalg og kompetanseoppnåelse i videregående opplæring blant 9749 ungdommer som gikk ut av grunnskolen på Østlandet våren 2002. Hovedfunn, konklusjoner og implikasjoner tre og et halvt år etter [Differences between people - what do schools do? Choice, dropout and competence achievement in upper secondary education among 9749 youths finishing secondary school in south-eastern Norway, spring 2002. Main findings, conclusions, and implications three and a half years later].NIFU Step Report 3-2006. https://nifu.brage.unit.no/nifu-xmlui/handle/11250/275569

Miles, M. B., Huberman, A. M., \& Saldaña, J. (2014). Qualitative data analysis: A methods sourcebook. Sage.

NOU (2018: 15). Kvalifisert, forberedt og motivert - Et kunnskapsgrunnlag om struktur og innhold i videregående opplæring [Qualified, prepared, and motivated - A knowledge base on structure and content in upper secondary education]. Oslo:

Kunnskapsdepartementet. https://www.regjeringen.no/no/dokumenter/nou-201815/id2621801/

O’Brennan, L. M., \& Furlong, M. J. (2010). Relations between students' perceptions of school connectedness and peer victimization. Journal of School Violence, 9(4), 375-391. https://doi.org/10.1080/15388220.2010.509009

Osterman, K. F. (2000). Students' need for belonging in the school community. Review of Educational Research, 70(3), 323-367. https://doi.org/10.3102/00346543070003323

Rogstad, J., \& Reegård, K. (2016). De frafalne: Om frafall i videregående opplering - hvem er de, hva vil de og hva kan gjøres? [Dropouts in upper secondary education - who are they, what do they aim for, and what can be done?] Gyldendal Akademisk.

Schachner, M. K., Schwarzenthal, M., van de Vijver, F. J. R., \& Noack, P. (2019). How all students can belong and achieve: Effects of the cultural diversity climate amongst students of immigrant and nonimmigrant background in Germany. Journal of Educational Psychology, 111(4), 703-716. https://doi.org/10.1037/edu0000303

Sen, A. (2006). Identity and violence. The illusion of destiny. Penguin Books.

Silverman, D. (2000). Analysing talk and text. In N. K. Denzin \& Y. S. Lincoln (Eds.), Handbook of qualitative research (pp. 821-834). Sage.

Simon, F., Malgorzata, K., \& Beatriz, P. (2007). Education and training policy no more failures: Ten steps to equity in education. OECD Publishing. 
Skrefsrud, T.-A., \& Østberg, S. (2015). Diversitet i lærerutdanningene - bidrag til en profesjonsorientert forståelse av fag og kunnskapsområder [Diversity in teacher education - contribution to a profession-oriented understanding of subjects and areas of knowledge]. Norsk Pedagogisk Tidsskrift, 99(3-4), 208-219. https://doi.org/10.18261/ISSN1504-29872015-03-04-05

Solbue, V., Helleve, I., \& Smith, K. (2017). "In this class we are so different that I can be myself!” Intercultural dialogue in a first grade upper secondary school in Norway. Education Inquiry, 8(2), 137-150. https://doi.org/10.1080/20004508.2017.1290894

SSB (2018). Videregående opplering og annen videregående utdanning [Upper secondary education]. Oslo: Statistics Norway. https://www.ssb.no/utdanning/statistikker/vgu

SSB (2019). Gjennomføring i videregående opplering [Completion of upper secondary education]. Oslo: Statistics Norway. https://www.ssb.no/vgogjen and https://www.ssb.no/statbank/table/11224/tableViewLayout1/

St-Amand, J., Girard, S., \& Smith, J. (2017). Sense of belonging at school: Defining attributes, determinants, and sustaining strategies. IAFOR Journal of Education, 5(2), 105-119. https://doi.org/10.22492/ije.5.2.05

Tartakovsky, E. (2007). A longitudinal study of acculturative stress and homesickness: Highschool adolescents immigrating from Russia and Ukraine to Israel without parents. Social Psychiatry and Psychiatric Epidemiology, 42(6), 485-494. https://doi.org/10.1007/s00127-007-0184-1

Thapa, A., Cohen, J., Guffey, S., \& Higgins-D’Alessandro, A. (2013). A review of school climate research. Review of Educational Research, 83(3), 357-385. https://doi.org/10.3102/0034654313483907

Tjora, A. H. (2017). Kvalitative forskningsmetoder i praksis [Qualitative research methods in practice]. Gyldendal Akademisk. 